\title{
Diagnosis and Treatment of Myeloproliferative Neoplasms With PCM1-JAK2 Rearrangement: Case Report and Literature Review
}

\author{
Yingxin Sun ${ }^{1,2 \dagger}$, Yifeng Cai ${ }^{3 \dagger}$, Jia Chen ${ }^{1,2}$, Jiannong Cen ${ }^{1,2}$, Mingqing Zhu ${ }^{1,2}$, \\ Jinlan Pan ${ }^{1,2}$, Depei Wu ${ }^{1,2}$, Aining Sun ${ }^{1,2}$ and Suning Chen ${ }^{1,2 *}$ \\ 1 Department of Hematology, First Affiliated Hospital of Soochow University, National Clinical Research Center for \\ Hematologic Diseases, Jiangsu Institute of Hematology, Soochow University, Suzhou, China, ${ }^{2}$ Department of Thrombosis \\ and Hemostasis, Key Laboratory of Thrombosis and Hemostasis of Ministry of Health, Suzhou, China, ${ }^{3}$ Department of \\ Hematology, The Affiliated Hospital of Nantong University, Nantong University, Nantong, China
}

OPEN ACCESS

Edited by:

Argiris Symeonidis,

University of Patras, Greece

Reviewed by:

Angelo Michele Carella,

Casa Sollievo della Sofferenza

(IRCCS), Italy

Yi Miao,

Nanjing Medical University, China

*Correspondence: Suning Chen

chensuning@suda.edu.cn

${ }^{t}$ These authors have contributed equally to this work

Specialty section:

This article was submitted to Hematologic Malignancies, a section of the journal

Frontiers in Oncology

Received: 05 August 2021 Accepted: 22 September 2021

Published: 11 October 2021

Citation:

Sun Y, Cai Y, Chen J, Cen J, Zhu M, Pan J, Wu D, Sun A and Chen S (2021)

Diagnosis and Treatment of

Myeloproliferative Neoplasms With

PCM1-JAK2 Rearrangement: Case

Report and Literature Review.

Front. Oncol. 11:753842.

doi: 10.3389/fonc.2021.753842
Myeloproliferative neoplasm (MPN) with PCM1-JAK2 rearrangement is a rare disease with poor prognosis and lacks uniform treatment guidelines. Several studies confirmed the efficacy of ruxolitinib in hematological malignancies with PCM1-JAK2 fusion, but the efficacy is variable. Here, we report two patients diagnosed with MPN with PCM1-JAK2 fusion who were treated with ruxolitinib-based regimen, including the first case of ruxolitinib combined with pegylated interferon (Peg-IFN), and we conduct a literature review. We found that ruxolitinib combined with Peg-IFN is an effective treatment option in the case of poor efficacy of ruxolitinib monotherapy.

Keywords: myeloproliferative neoplasms, PCM1-JAK2, ruxolitinib, pegylated interferon, case report

\section{INTRODUCTION}

JAK2 components play an important role in hematopoiesis, cell proliferation, and differentiation. Abnormal activation of JAK pathway by gene mutations or rearrangements is common in Philadelphia-negative myeloproliferative neoplasm (MPN). About $75 \%$ of typical Philadelphianegative MPN, including essential thrombocytosis (ET), polycythemia vera (PV), and primary myelofibrosis (PMF), carry a specific V617F somatic mutation in JAK2 gene $(1,2)$. In contrast, chromosomal translocations involving JAK2 gene are rare and have been reported in various hematological malignancies. Among them, the PCM1-JAK2 fusion gene derived from $t(8 ; 9)(\mathrm{p} 22$; p24) is the most frequent (3-7). MPN with PCM1-JAK2 rearrangement is accompanied by varying degrees of eosinophilia, lymphadenopathy/hepatosplenomegaly, and myelofibrosis (8). Based on share characteristics, myeloid/lymphoid neoplasms (MLNs) with PCM1-JAK2 rearrangement has been added as a provisional entity in the 2016 World Health Organization (WHO) classification of myeloid neoplasms and acute leukemia (9).

MLN with PCM1-JAK2 rearrangement is a rare disease with poor prognosis and lacks unified treatment guidelines. Up to now, allogeneic hematopoietic stem cell transplantation (allo-HSCT) is the only way that can cure the disease. Ruxolitinib, a JAK2 inhibitor, has been approved by the United States Food and Drug Administration for the treatment of intermediate- and high-risk PMF 
according to the findings of two randomized controlled trials (10, 11). However, ruxolitinib is not yet approved for MPN with PCM1-JAK2 rearrangement, although it has been shown to be effective. Here, we report two patients with MPN with PCM1JAK2 fusion who received ruxolitinib-based regimen, one of which is the first report of ruxolitinib combined with pegylated interferon (Peg-IFN) at home and abroad.

\section{CASE PRESENTATION}

\section{Case 1}

In October 2020, a 42-year-old man was referred to our department because of leukocytosis (leukocyte $48.4 \times 10^{9} / \mathrm{L}$ ) with eosinophilia (eosinophils $3.97 \times 10^{9} / \mathrm{L}$ ), mononucleosis (monocyte $1.9 \times 10^{9} / \mathrm{L}$ ), and anemia (hemoglobin $106 \mathrm{~g} / \mathrm{L}$ ). The platelet count is normal $\left(159 \times 10^{9} / \mathrm{L}\right)$. The morphological test of peripheral blood showed that eosinophils accounted for $9 \%$, monocytes accounted for $9 \%$, and blasts accounted for $1 \%$. Ultrasound showed that the spleen is slightly larger (length 13.2 $\mathrm{cm}$ ) without lymphadenopathy and hepatomegaly. The bone marrow analyses showed hypercellular morphology (myeloblast $2 \%$, monoblast $2 \%$, promonocyte $9 \%$, and eosinophilia) with dyshematopoiesis in granule and erythroid linages, but no evidence of myelofibrosis. Bone marrow immunohistochemistry: myeloperoxidase (3+), glycophorin A (2+), CD3 (-), CD20 (-), CD38 (-), and CD34 (-). Chromosomal analysis showed a karyotype of $46, \mathrm{XY}, \mathrm{t}(8 ; 9)$. Targeted next-generation sequencing (NGS) was negative. RNA sequencing revealed that exon 36 of PCM1 was fused to exon 8 of JAK2. In conclusion, the patient was diagnosed with MLN with eosinophilia (MLN-Eo) and PCM1JAK2 rearrangement according to the 2016 WHO criteria (12).

Induction treatment for the patient was hydroxyurea (HU; 500 $\mathrm{mg} \mathrm{qd}$ ) combined with ruxolitinib (with initiating dose of $5 \mathrm{mg}$ qd and then escalated to $15 \mathrm{mg}$ bid). The patient achieved complete hematologic remission (CHR) in 1 month and then accepted the maintenance therapy with ruxolitinib alone. Subsequently, his leukocytes and eosinophils progressively increased, accompanied by a reduction of platelet counts. Two and a half months after stopping $\mathrm{HU}$, the patient complained of abdominal distension, and abdominal Doppler ultrasound indicated that the spleen was $3.5 \mathrm{~cm}$ below the ribs. PCM1-JAK2 quantitative PCR test indicated $109.17 \%$ (no data at diagnosis). In addition to ruxolitinib, Peg-IFN (90 $\mu$ g s.c. qw) and HU (500 mg bid) were administered. The patient tolerated the combined treatment well. Assessment conducted 2 months later showed that leukocytes, eosinophils, and platelets were significantly improved, the spleen size returned to normal, and PCM1-JAK2 fusion transcript decreased to $37.03 \%$. These results suggested that the combination of ruxolitinib and Peg-IFN was safe and effective. Currently, the patient is still receiving combined therapy, and he is planning to undergo haploidentical HSCT (Figure 1A).

\section{Case 2}

In December 2020, a 47-year-old man was referred to the hematological department complaining of fatigue, tinnitus, and dizziness for 2 months. Count of blood cells test showed leukocytes of $13.47 \times 10^{9} / \mathrm{L}$, eosinophils of $2.52 \times 10^{9} / \mathrm{L}$, severe anemia (hemoglobin $66 \mathrm{~g} / \mathrm{L})$, and normal platelet counts $(117 \times$ $\left.10^{9} / \mathrm{L}\right)$. Peripheral blood smear revealed the presence of immature granulocytes and erythrocytes, with teardrop-like erythrocytes and 14\% eosinophils. Physical examination suggested hepatosplenomegaly. The bone marrow morphology was hypercellular and showed granulocytic proliferation with eosinophilic proliferation, reduced erythropoiesis, hyperplasia of megakaryocytes, and grade 0-1 fibrosis according to European Myelofibrosis Network criteria (13). Cytogenetic analysis demonstrated a normal male karyotype. NGS was negative. Fluorescence in situ hybridization study demonstrated that BCR-ABL1, BCR-JAK2, ETV6-JAK2, ETV-FLT3, ETV-ABL1, PDGFRA, PDGFRB, and FGFR1 fusion and rearrangement were all negative. The PCM1-JAK2 fusion transcript was identified by reverse transcription polymerase chain reaction (RT-PCR). The break site was located in exon 36 of PCM1 and exon 9 of JAK2. The diagnosis of MLN-Eo with PCM1-JAK2 fusion was established. The patient returned to the local hospital for treatment and was treated with HU (500 mg tid), ruxolitinib (15 mg bid), and red blood cell transfusion after patient informed consent. According to the white blood cell counts, HU was discontinued after 0.5 months. One month later, the patient's white blood cells $\left(1.66 \times 10^{9} / \mathrm{L}\right)$ and eosinophils $\left(0.30 \times 10^{9} / \mathrm{L}\right)$ decreased significantly, the hepatosplenomegaly was improved, and the platelet $\left(48 \times 10^{9} / \mathrm{L}\right)$ decreased, so the dose of ruxolitinib was reduced. However, both white blood cells and eosinophils were progressively increased since the dose of ruxolitinib was reduced. The final dose of ruxolitinib was maintained at 10 and $15 \mathrm{mg}$ alternately every day. During the treatment of ruxolitinib, there was Grade 3 leukopenia and Grade 4 thrombocytopenia. Later, the patient developed a huge spleen, which was considered to be related to the insufficient dose of ruxolitinib. In short, the patient cannot tolerate the therapeutic dose of ruxolitinib and is preparing for allo-HSCT (Figure 1B).

\section{DISCUSSION}

So far, 68 cases of PCM1-JAK2 fusion have been reported in hematological malignancies, most commonly in myelodysplastic syndrome (MDS)/MPN and MPN. The median age is 50 years (12-86 years), the male to female ratio is $3.17: 1,83.61 \%$ of patients have varying degrees of eosinophilia, and $50 \%$ of patients have myelofibrosis (Table $\mathbf{1}$ and Figure 2). Thirteen patients were treated with ruxolitinib \pm HSCT, of which 11 were myeloid neoplasms and two were lymphatic neoplasms. Twelve were responsive to ruxolitinib, and one was of uncertain efficacy; however, the duration of response varied widely (Table 2 ). The 2021 National Comprehensive Cancer Network (NCCN) guidelines for MLN-Eo with PCM1-JAK2 fusion recommend that clinical trial is the preferred treatment option for patients with chronic phase disease, and patients with chronic phase disease can be treated with tyrosine kinase inhibitor (TKI) monotherapy in the absence of a clinical trial. However, early 

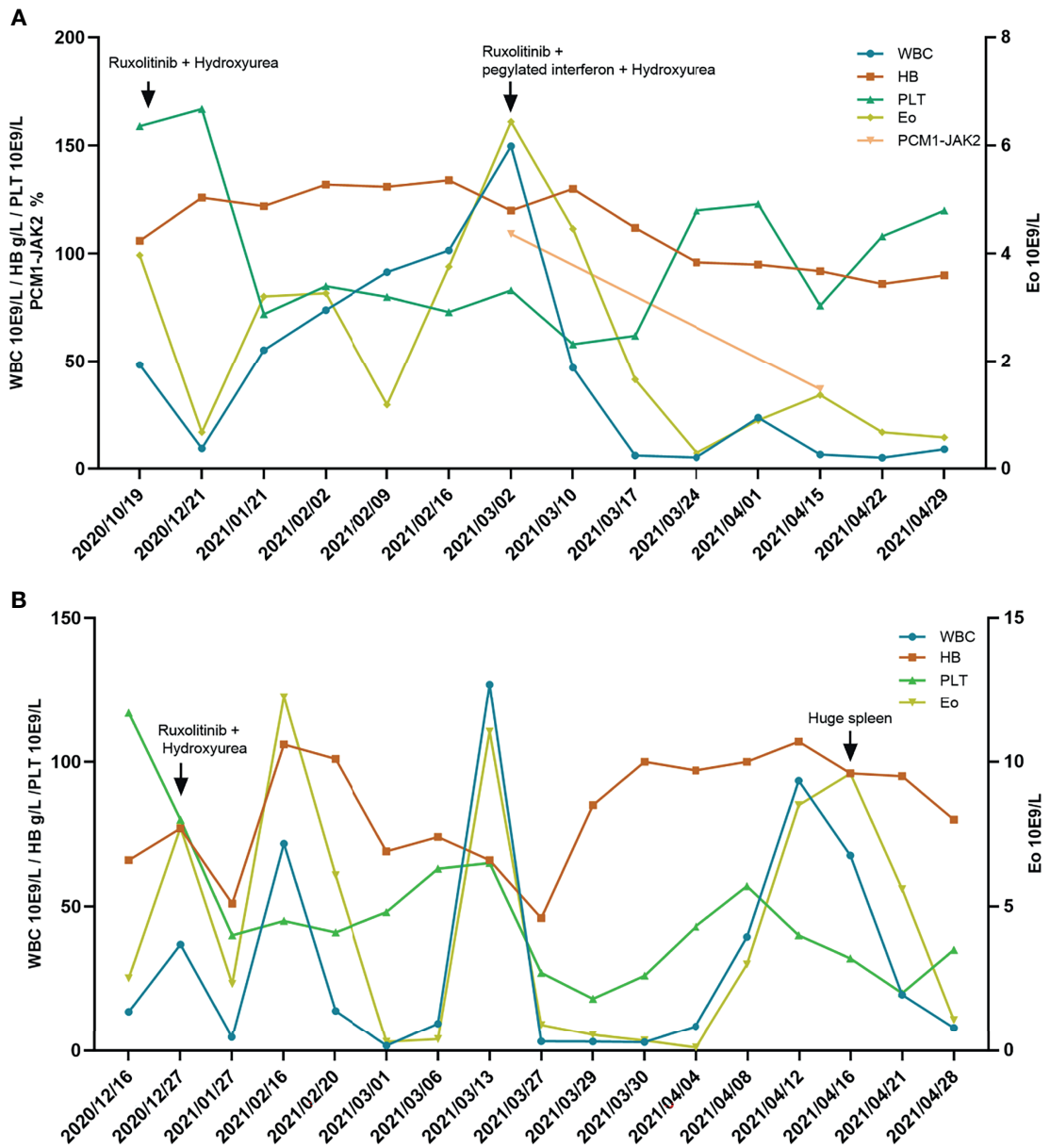

FIGURE 1 | (A) The blood cell and PCM1-JAK2 fusion transcript changes in patient 1 over the course of the disease. (B) The blood cell changes in patient 2 over the course of the disease. WBC, white blood cells; HB, hemoglobin; PLT, platelet; Eo, eosinophils.

referral to allo-HSCT should be considered for eligible patients, since TKI therapy alone does not result in durable remissions. We report two male cases diagnosed as MLN-Eo with PCM1-JAK2 fusion. Patient 1 was initially treated with ruxolitinib and HU to obtain instant CHR but later experienced progressive increase of white blood cells and eosinophils, which indicated treatment failure. The effect was regained after the addition of Peg-IFN, and PCM1-JAK2 fusion transcript decreased significantly, suggesting that molecular response was obtained. As far as we know, this is the first report of MLN-Eo and PCM1-JAK2 fusion receiving ruxolitinib combined with Peg-IFN at home and abroad. Unfortunately, limited by short follow-up time, we have not observed patients obtained complete molecular response (CMR). Patient 2 initially responded to treatment with ruxolitinib and $\mathrm{HU}$, but it was discontinued due to intolerant hematological toxicity. Both cases indicated the effectiveness of ruxolitinib in MLN-Eo with PCM1-JAK2 fusion, despite different durations of response and toxicity, and both patients will undergo HSCT.

PCM1-JAK2 rearrangement has been reported in a variety of hematological neoplasms (3-7), which indicates that the PCM1-
JAK2 rearrangement lacks lineage specificity. Because of the abnormality of the JAK2 signaling pathway in these diseases, treatment with ruxolitinib may be effective. Previous documents confirmed that ruxolitinib can inhibit the growth of PCM1-JAK2 transformed $\mathrm{Ba} / \mathrm{F} 3$ mouse cells in vitro and the phosphorylation of JAK-STAT5 pathway (18). Lierman (18) and colleagues reported the first case of ruxolitinib in myeloproliferative disease with PCM1-JAK2 rearrangement. A 72-year-old male diagnosed with chronic eosinophilic leukemia (CEL) of PCM1JAK2 rearrangement received ruxolitinib alone $10-20 \mathrm{mg}$ twice daily, achieved complete cytogenetic response (CCyR) after 15 months, and was recurrence-free after 36 months (31). Subsequently, Rumi et al. (21) reported a second similar case. A 31-year-old woman was diagnosed with CEL with PCM1JAK2 rearrangement. She was treated with ruxolitinib $15 \mathrm{mg}$ twice, acquired complete clinical remission 1 year later, and attained CCyR 46 months later, with a significant decrease in the fusion transcript (31). These cases indicated that ruxolitinib is valuable for MPN with PCM1-JAK2 rearrangement and could induce long-term remission. Schwaab et al. (23) identically 
TABLE 1 | Hematological neoplasms with PCM1-JAK2 fusion from literature.

\begin{tabular}{|c|c|c|c|}
\hline Authors & Time & Journals & Number of cases \\
\hline Reiter et al. (5) & 2005 & Cancer Research & 7 \\
\hline Bousquet et al. (4) & 2005 & Oncogene & 2 \\
\hline Murati et al. (3) & 2005 & Leukemia & 4 \\
\hline Heiss et al. (14) & 2005 & Human Pathology & 1 \\
\hline Adélaïde et al. (6) & 2006 & Leukemia & 1 \\
\hline Huang et al. (15) & 2008 & International Journal of Hematology & 1 \\
\hline Dargent et al. (16) & 2011 & European Journal of Haematology & 1 \\
\hline Prochorec-Sobieszek et al. (17) & 2012 & Leukemia \& Lymphoma & 1 \\
\hline Lierman et al. (18) & 2012 & Blood & 1 \\
\hline Masselli et al. (19) & 2013 & British Journal of Haematology & 1 \\
\hline Patterer et al. (20) & 2013 & Annals of Hematology & 6 \\
\hline Rumi et al. (21) & 2013 & Journal of Clinical Oncology & 1 \\
\hline Saba et al. (22) & 2013 & Blood & 1 \\
\hline Schwaab et al. (23) & 2015 & Annals of Hematology & 1 \\
\hline Song et al. (24) & 2016 & Annals of Laboratory Medicine & 1 \\
\hline Baer et al. (25) & 2018 & Haematologica & 7 \\
\hline Lee et al. (26) & 2018 & Annals of Laboratory Medicine & 1 \\
\hline Riedlinger et al. (7) & 2019 & JCO Precision Oncology & 1 \\
\hline Salehi et al. (27) & 2019 & Leukemia \& Lymphoma & 1 \\
\hline Tang et al. (8) & 2019 & Modern Pathology & 10 \\
\hline Schwaab et al. (28) & 2020 & American Journal of Hematology & 8 \\
\hline Wouters et al. (29) & 2021 & British Journal of Haematology & 1 \\
\hline Pozdnyakova et al. (30) & 2021 & American Journal of Clinical Pathology & 9 \\
\hline
\end{tabular}

confirmed that ruxolitinib was valuable in myeloid neoplasms with PCM1-JAK2 fusion, but the patient relapsed after 24 months on ruxolitinib. Recently, Schwaab et al. (28) reported a series of nine myeloid malignancy cases treated with ruxolitinib alone as first-line treatment, including eight cases of PCM1-JCK2 rearrangement and one case of BCR-JAK2 rearrangement. With a median time of 4 months (range 2-18 months), five patients achieved CHR. CCyR or CMR was observed in one patient. Their data showed that all the patients did not have long-term beneficial effects with ruxolitinib. In brief, the efficacy of ruxolitinib in MPN with PCM1-JAK2 fusion is inconsistent, with some patients surviving for a long time after ruxolitinib treatment and others relapsing early. There are also differences in the efficacy of ruxolitinib in lymphoid neoplasms with abnormal JAK2 pathway. Recent data (29) reported that an elderly woman diagnosed with B-cell acute lymphoblastic leukemia (B-ALL) with PCM1-JAK2 rearrangement failed to obtain complete cytogenetic and molecular biological response after receiving traditional chemotherapy and immunotherapy. Within 1 year after ruxolitinib $10 \mathrm{mg}$ bid treatment, the PCM1-JAK2 fusion

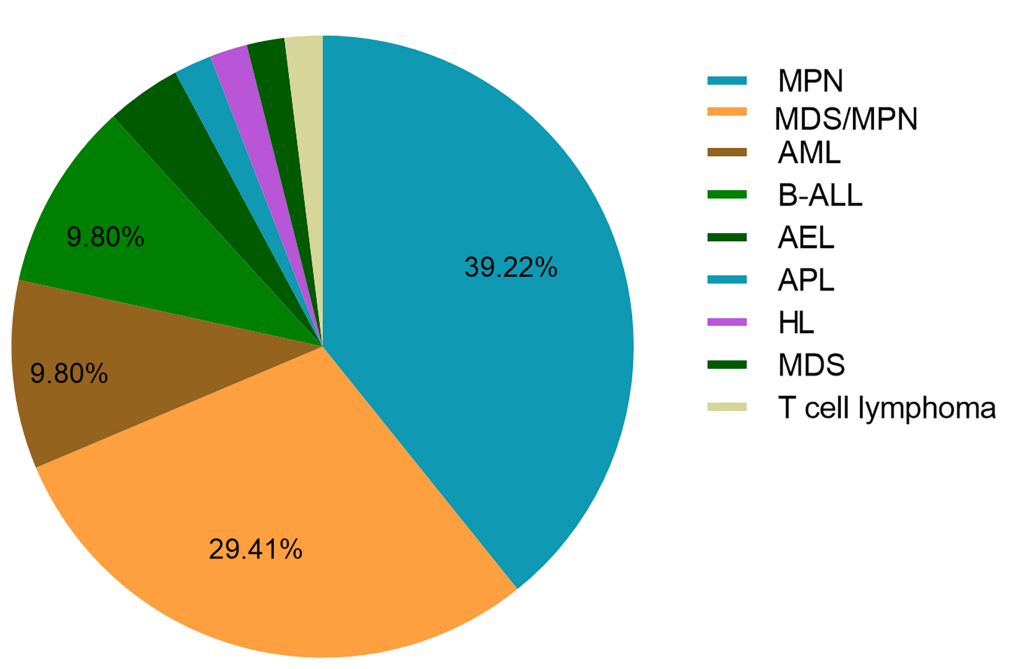

FIGURE 2 | Distribution of PCM1-JAK2 fusion in hematological neoplasms in the literature. MPNs, myeloproliferative neoplasms; MDS/MPN, myelodysplastic syndrome/myeloproliferative neoplasms; AML, acute myeloid leukemia; B-ALL, B-cell acute lymphoblastic leukemia; AEL, acute erythroid leukemia; APL, acute promyelocytic leukemia; HL, Hodgkin lymphoma. 
TABLE 2 | Clinical characteristics of hematological neoplasms patients with PCM1-JAK2 rearrangement treated with ruxolitinib in the literature.

\begin{tabular}{|c|c|c|c|c|c|c|c|c|c|c|}
\hline $\begin{array}{l}\text { Case } \\
\text { no. }\end{array}$ & Age & Gender & Diagnosis & $\begin{array}{c}\text { WBC } \\
\left(\times 10^{9} / \text { L }\right)\end{array}$ & $\begin{array}{l}\text { Eo } \\
(\%)\end{array}$ & Splenomegaly & Bone marrow & Karyotype & Treatment & Clinical course \\
\hline A1 & 72 & M & CEL, NOS & 49 & 46.9 & NA & $\begin{array}{l}\text { Granulocytosis } \\
\text { and eosinophilia }\end{array}$ & t(8;9)(p22;p24) & $\begin{array}{l}\mathrm{HU} \text { and } \\
\text { ruxolitinib }\end{array}$ & $\begin{array}{l}\text { CCyR was obtained after } 15 \text { months } \\
\text { on ruxolitinib. }\end{array}$ \\
\hline B2 & 50 & M & MPN & 9.9 & 6 & Yes & $\begin{array}{l}\text { Granulopoiesis, } \\
\text { left-shifted and } \\
\text { eosinophilia }\end{array}$ & t(8;9)(p22;p24) & Ruxolitinib & Alive 16 months after diagnosis. \\
\hline $\mathrm{C} 3$ & 31 & $\mathrm{~F}$ & CEL, NOS & 21.6 & 16.2 & Yes & $\begin{array}{l}\text { Granulopoiesis, } \\
\text { eosinophilia, } \\
\text { immature } \\
\text { erythroid cells, } \\
\text { and MF } 1\end{array}$ & t(8;9)(p22;p24) & $\begin{array}{l}\text { Imatinib, HU, } \\
\text { and ruxolitinib }\end{array}$ & $\begin{array}{l}\text { No response to imatinib; then } \\
\text { complete clinical remission was } \\
\text { achieved after ruxolitinib. }\end{array}$ \\
\hline D4 & 51 & M & MPN & 12 & NA & Yes & $\begin{array}{l}\text { Granulopoiesis, } \\
\text { eosinophilia, } \\
\text { dysplastic } \\
\text { erythropoiesis, } \\
\text { and MF } 2\end{array}$ & t(8;9)(p22;p24) & Ruxolitinib & $\begin{array}{l}\text { CCyR was obtained after } 12 \text { months } \\
\text { on ruxolitinib, but cytogenetic relapse } \\
\text { occurred after } 24 \text { months. }\end{array}$ \\
\hline E5 & 40 & M & MPN & 5.4 & 16 & Yes & $\begin{array}{l}\text { Eosinophils, } \\
\text { immature } \\
\text { erythroid } \\
\text { precursors and } \\
\text { MF 1-2 }\end{array}$ & t(8;9)(p22;p24) & $\begin{array}{l}\text { Ruxolitinib and } \\
\text { HSCT }\end{array}$ & $\begin{array}{l}\text { No disease progression during the } \\
\text { follow-up period. }\end{array}$ \\
\hline F6 & 76 & M & $\begin{array}{l}\text { CML-like } \\
\text { MPN }\end{array}$ & 28.7 & 5 & No & $\begin{array}{l}\text { Eosinophilia, } \\
\text { left-shifted, } \\
\text { dysplastic, and } \\
\text { MF } 2\end{array}$ & t(8;9)(p22;p24) & Ruxolitinib & $\begin{array}{l}\text { Disease progression after } 1 \text { month } \\
\text { on ruxolitinib. }\end{array}$ \\
\hline F7 & 70 & M & $\mathrm{aCML}$ & 29.8 & 1 & Yes & $\begin{array}{l}\text { Eosinophilia, } \\
\text { left-shifted, } \\
\text { dysplastic and } \\
\text { MF } 1\end{array}$ & t(8;9)(p22;p24) & Ruxolitinib & $\begin{array}{l}\text { CHR was obtained after } 2 \text { months } \\
\text { on ruxolitinib. }\end{array}$ \\
\hline F8 & 49 & $M$ & MDS/MPN & 25.6 & NA & Yes & $\begin{array}{l}\text { Eosinophilia, } \\
\text { left-shifted, } \\
\text { dysplastic and } \\
\text { MF } 2\end{array}$ & $\begin{array}{l}\mathrm{t}(8 ; 9 ; 9)(\mathrm{p} 22 ; \mathrm{p} 24 ; \\
\mathrm{p} 13)\end{array}$ & $\begin{array}{l}\text { Ruxolitinib and } \\
\text { HSCT }\end{array}$ & $\begin{array}{l}\text { CHR was obtained after } 2 \text { months } \\
\text { on ruxolitinib, and the disease } \\
\text { progressed } 36 \text { months later, } \\
\text { followed by HSCT. }\end{array}$ \\
\hline F9 & 29 & $M$ & $\begin{array}{l}\text { CML-like } \\
\text { MPN }\end{array}$ & 21.7 & 11 & Yes & NA & t(8;9)(p22;p24) & $\begin{array}{l}\text { Ruxolitinib and } \\
\text { HSCT }\end{array}$ & $\begin{array}{l}\text { CHR was obtained after } 2 \text { months } \\
\text { on ruxolitinib, followed by HSCT. }\end{array}$ \\
\hline F10 & 50 & $M$ & MDS/MPN & 12.7 & 13 & Yes & $\begin{array}{l}\text { Eosinophilia, } \\
\text { left-shifted, } \\
\text { dysplastic, and } \\
\text { MF } 2\end{array}$ & t(8;9)(p22;p24) & $\begin{array}{l}\text { Ruxolitinib and } \\
\text { HSCT }\end{array}$ & $\begin{array}{l}\text { CHR was obtained after } 18 \text { months } \\
\text { on ruxolitinib, and the disease } \\
\text { progressed } 8 \text { months later, followed } \\
\text { by HSCT. }\end{array}$ \\
\hline F11 & 69 & $\mathrm{~F}$ & AML-M4 & 10.5 & 1 & No & $\begin{array}{l}\text { Blasts } 20 \% \text { and } \\
\text { MF } 3\end{array}$ & $\begin{array}{l}\mathrm{t}(8 ; 9)(\mathrm{p} 22 ; \mathrm{p} 24),+6 \\
+8,+22\end{array}$ & $\begin{array}{l}\text { Ruxolitinib and } \\
\text { azacitidine }\end{array}$ & $\begin{array}{l}\text { The disease progressed after } 2 \\
\text { months on ruxolitinib, CHR was } \\
\text { obtained after } 3 \text { months on } \\
\text { azacitidine, and the disease } \\
\text { progressed again after } 9 \text { months. }\end{array}$ \\
\hline F12 & 63 & M & $\begin{array}{l}\text { Pre-B- } \\
\text { ALL }\end{array}$ & 55.2 & NO & No & Sheets of blasts & t(8;9)(p22;p24) & $\begin{array}{l}\text { Ruxolitinib and } \\
\text { HSCT }\end{array}$ & $\begin{array}{l}\text { HSCT followed by ruxolitinib; then } \\
\text { disease progressed. }\end{array}$ \\
\hline G13 & 77 & $\mathrm{~F}$ & B-ALL & 32.6 & $\mathrm{NO}$ & No & $87 \%$ blasts & $\begin{array}{l}\text { t(8;9)(p22;p24)[1]/ } \\
\text { 46,sl,der(8;9)(q10; } \\
\text { q10),inc [5]/46,X,t } \\
(X ; 4)(p 1 ? 1 ; q 13)[4] / \\
46, X X[10]\end{array}$ & $\begin{array}{l}\text { Chemotherapy, } \\
\text { blinatumomab, } \\
\text { and ruxolitinib }\end{array}$ & $\begin{array}{l}\text { PCM1-JAK2 fusion transcript was } \\
23.28 \% \text { after chemotherapy } \\
\text { combined with blinatumomab, which } \\
\text { decreased to } 3.22 \% \text { after the } \\
\text { addition of ruxolitinib. }\end{array}$ \\
\hline
\end{tabular}

M, man; F, female; WBC, white blood cells; Eo, eosinophils; CEL, NOS, Chronic eosinophilic leukemia, not otherwise specified; CML, chronic myeloid leukemia; aCML, atypical chronic myeloid leukemia; CCyR, complete cytogenetic remission; NA, not available. Case A: (Lierman et al.) (18). Case B: (Patterer et al.) (20). Case C: (Rumi et al.) (21). Case D: (Schwaab et al.) (23). Case E: (Tang et al.) (8). Case F: (Schwaab et al.) (28). Case G: Wouters et al.) (29).

transcript and abnormal metaphase were significantly reduced, but none of them disappeared completely. Another young female patient with relapsed and refractory B-ALL with RNPC3-JAK2 fusion did not respond to chemotherapy combined with immunotherapy and ruxolitinib (32). Mayfield et al. (33) documented that a 17 -year-old B-ALL patient with JAK2 F694L mutation persisted with minimal residual disease
(MRD) after standard chemotherapy, while the MRD turned out to be negative after the integration of ruxolitinib $20 \mathrm{mg}$ bid for 2 weeks. The research of Ding (34) and his coworkers found that high-dose ruxolitinib combined with multidrug chemotherapy was safe and effective for children with BCRABL1-like ALL, and whether the combination therapy is suitable for MPN with PCM1-JAK2 fusion is worth exploring. 
In summary, there have been considerable evidences that ruxolitinib is effective in hematological malignancies with abnormal JAK2 signaling pathways, although the efficacy is highly heterogeneous. The heterogeneity may be partially attributed to different somatic mutations or blastic crisis of MPN (8).

No somatic mutations were detected in both of our patients. Due to the rarity of hematological neoplasms with PCM1-JAK2 rearrangement, it is difficult to conduct large-scale clinical studies. Thus, there are no large cohort data on the molecular characterization of PCM1-JAK2-rearranged hematologic neoplasms. Baer et al. (25) found that mutation rates were 14\% (1/7) for hematologic neoplasms with PCM1-JAK2 rearrangement, and the patient had TET2 somatic mutations. We speculate that somatic mutations of epigenetic regulators may be present in hematologic neoplasms with PCM1JAK2 fusion, so hypomethylating-agent-based programs may be effective. Dargent et al. (16) described the diagnosis and treatment of a patient with MDS/MPN with PCM1-JAK2 fusion. The initial analysis of bone marrow karyotype was normal, but $t(8 ; 9)$ was detected by fluorescence in situ hybridization analysis in peripheral blood. The author suggested that $\mathrm{t}(8 ; 9)(\mathrm{p} 22 ; \mathrm{p} 24)$ was not easy to detect in the study of G-banding and was easy to be ignored, especially in poor specimens. Tang (8) and his colleagues also noted that because $t(9 \mathrm{p} 24.1 ; \mathrm{V})$ only involved small segments of the $9 \mathrm{p}$ chromosome, such rearrangements were cryptic and therefore missed by routine chromosome analysis. These explain the reason for the normal karyotype of patient 2 .

\section{CONCLUSION}

MLN-Eo with PCM1-JAK2 rearrangement is rare and has a poor prognosis. Existing data have shown that ruxolitinib is effective for the disease, but allo-HSCT is still the only way to cure the disease. Ruxolitinib can be used as a bridging treatment before allo-HSCT. Here, we reported the efficacy and safety of ruxolitinib in MPN with PCM1-JAK2 rearrangement. For patients with low efficacy of ruxolitinib monotherapy or rapid disease progression, the treatment options to obtain cytogenetics or molecular response prior to HSCT warrant further study. Ruxolitinib combined with Peg-IFN could be one of the candidates.

\section{REFERENCES}

1. James C, Ugo V, Le Couédic J-P, Staerk J, Delhommeau F, Lacout C, et al. A Unique Clonal JAK2 Mutation Leading to Constitutive Signalling Causes Polycythaemia Vera. Nature (2005) 434:1144-8. doi: 10.1038/nature03546

2. Kralovics R, Passamonti F, Buser AS, Teo S, Tiedt R, Passweg JR, et al. A Gain-of-Function Mutation of JAK2 in Myeloproliferative Disorders. New Engl J Med (2005) 352:1779-90. doi: 10.1056/NEJMoa051113

3. Murati A, Gelsi-Boyer V, Adélaïde J, Perot C, Talmant P, Giraudier S, et al. PCM1-JAK2 Fusion in Myeloproliferative Disorders and Acute Erythroid Leukemia With T(8;9) Translocation. Leukemia (2005) 19:1692-6. doi: 10.1038/sj.leu.2403879

4. Bousquet M, Quelen C, De Mas V, Duchayne E, Roquefeuil B, Delsol G, et al. The T(8;9)(P22;P24) Translocation in Atypical Chronic Myeloid Leukaemia Yields a New PCM1-JAK2 Fusion Gene. Oncogene (2005) 24:7248-52. doi: $10.1038 /$ sj.onc. 1208850

\section{DATA AVAILABILITY STATEMENT}

The original contributions presented in the study are included in the article/supplementary material. Further inquiries can be directed to the corresponding author.

\section{ETHICS STATEMENT}

The studies involving human participants were reviewed and approved by the Research Ethics Committee of the First Affiliated Hospital of Soochow University. The patients/participants provided their written informed consent to participate in this study.

\section{AUTHOR CONTRIBUTIONS}

YS wrote the manuscript. SC guided the treatment of cases. YC, JC, JNC, MZ, and JP performed the research and analyzed the data. All authors contributed to the article and approved the submitted version.

\section{FUNDING}

This study was supported by grants from the National Key R\&D Program of China (2019YFA0111000), the National Natural Science Foundation of China (81700140, 81873449, 81900130, $81970136,81970142,81970142,82000132$, and 82000158), the Natural Science Foundation of the Jiangsu Higher Education Institution of China (18KJA320005), the Natural Science Foundation of Jiangsu Province (BK20190180), priority academic program development of Jiangsu Higher Education Institution, the Innovation Capability Development Project of Jiangsu Province (BM215004), the Translational Research Grant of NCRCH (2020WSB03, 2020WSB11, and 2020WSB13), the Open Project of Jiangsu Biobank of Clinical Resources (SBK202003001 and SBK202003003), Jiangsu Provincial Key Medical Center (YXZXA2016002), and National Science and Technology Major Project (2017ZX09304021).

5. Reiter A, Walz C, Watmore A, Schoch C, Blau I, Schlegelberger B, et al. The T $(8 ; 9)(\mathrm{P} 22 ; \mathrm{P} 24)$ Is a Recurrent Abnormality in Chronic and Acute Leukemia That Fuses PCM1 to JAK2. Cancer Res (2005) 65:2662-7. doi: 10.1158/00085472.CAN-04-4263

6. Adélaïde J, Pérot C, Gelsi-Boyer V, Pautas C, Murati A, Copie-Bergman C, et al. A T(8;9) Translocation With PCM1-JAK2 Fusion in a Patient With T-Cell Lymphoma. Leukemia (2006) 20:536-7. doi: 10.1038/sj.leu.2404104

7. Riedlinger GM, Chojecki A, Aviv H, Weissmann D, Joshi S, Murphy SM, et al. Hodgkin Lymphoma and Cutaneous T-Cell Lymphoma Sharing the PCM1JAK2 Fusion and a Common T-Cell Clone. JCO Precis Oncol (2019) 1-8. doi: 10.1200/PO.19.00082

8. Tang G, Sydney Sir Philip JK, Weinberg O, Tam W, Sadigh S, Lake JI, et al. Hematopoietic Neoplasms With 9p24/JAK2 Rearrangement: A Multicenter Study. Modern Pathol (2019) 32:490-8. doi: 10.1038/s41379-018-0165-9

9. Gerds AT, Gotlib J, Bose P, Deininger MW, Dunbar A, Elshoury A, et al. Myeloid/Lymphoid Neoplasms With Eosinophilia and TK Fusion Genes, 
Version 3.2021, NCCN Clinical Practice Guidelines in Oncology. J Natl Compr Cancer Network (2020) 18:1248-69. doi: 10.6004/jnccn.2020.0042

10. Harrison C, Kiladjian J-J, Al-Ali HK, Gisslinger H, Waltzman R, Stalbovskaya V, et al. JAK Inhibition With Ruxolitinib Versus Best Available Therapy for Myelofibrosis. N Engl J Med (2012) 366:787-98. doi: 10.1056/ NEJMoa1110556

11. Verstovsek S, Mesa RA, Gotlib J, Levy RS, Gupta V, DiPersio JF, et al. A Double-Blind, Placebo-Controlled Trial of Ruxolitinib for Myelofibrosis. N Engl J Med (2012) 366:799-807. doi: 10.1056/NEJMoal110557

12. Arber DA, Orazi A, Hasseriian R, Thiele J, Borowitz MJ, Le Beau MM, et al. The 2016 Revision to the World Health Organization Classification of Myeloid Neoplasms and Acute Leukemia. Blood (2016) 127:2391-405. doi: 10.1182/blood-2016-03-643544

13. Thiele J, Kvasnicka HM, Facchetti F, Franco V, van der Walt J, Orazi A. European Consensus on Grading Bone Marrow Fibrosis and Assessment of Cellularity. Haematologica (2005) 90:1128-32.

14. Heiss S, Erdel M, Gunsilius E, Nachbaur D, Tzankov A. Myelodysplastic/ Myeloproliferative Disease With Erythropoietic Hyperplasia (Erythroid Preleukemia) and the Unique Translocation (8;9)(P23;P24): First Description of a Case. Hum Pathol (2005) 36:1148-51. doi: 10.1016/j.humpath.2005.07.020

15. Huang K-P, Chase AJ, Cross NCP, Reiter A, Li T-Y, Wang T-F, et al. Evolutional Change of Karyotype With $\mathrm{T}(8 ; 9)(\mathrm{P} 22 ; \mathrm{P} 24)$ and HLA-DR Immunophenotype in Relapsed Acute Myeloid Leukemia. Int J Hematol (2008) 88:197-201. doi: 10.1007/s12185-008-0113-4

16. Dargent J-L, Mathieux V, Vidrequin S, Deghorain X, Vannuffel P, Rack K. Pathology of the Bone Marrow and Spleen in a Case of Myelodysplastic/ Myeloproliferative Neoplasm Associated With T(8;9)(P22;P24) Involving PCM1 and JAK2 Genes. Eur J Haematol (2011) 86:87-90. doi: 10.1111/ j.1600-0609.2010.01525.x

17. Prochorec-Sobieszek M, Nasiłowska-Adamska B, Borg K, Kopeć I, KosZakrzewska K, Juszczyński P, et al. Chronic Eosinophilic Leukemia With Erythroblastic Proliferation and the Rare Translocation T(8;9)(P22;P24) With PCM1-JAK2 Fusion Gene: A Distinct Clinical, Pathological and Genetic Entity With Potential Treatment Target? Leukemia Lymphoma (2012) 53:1824-7. doi: 10.3109/10428194.2012.661856

18. Lierman E, Selleslag D, Smits S, Billiet J, Vandenberghe P. Ruxolitinib Inhibits Transforming JAK2 Fusion Proteins In Vitro and Induces Complete Cytogenetic Remission in T(8;9)(P22;P24)/PCM1-JAK2-Positive Chronic Eosinophilic Leukemia. Blood (2012) 120:1529-31. doi: 10.1182/blood-2012-06-433821

19. Masselli E, Mecucci C, Gobbi G, Carubbi C, Pierini V, Sammarelli G, et al. Implication of MAPK1/MAPK3 Signalling Pathway in T(8;9)(P22;24)/PCM1JAK2 Myelodysplastic/Myeloproliferative Neoplasms. Br J Haematol (2013) 162:563-6. doi: 10.1111/bjh.12392

20. Patterer V, Schnittger S, Kern W, Haferlach T, Haferlach C. Hematologic Malignancies With PCM1-JAK2 Gene Fusion Share Characteristics With Myeloid and Lymphoid Neoplasms With Eosinophilia and Abnormalities of PDGFRA, PDGFRB, and FGFR1. Ann Hematol (2013) 92:759-69. doi: 10.1007/s00277-013-1695-3

21. Rumi E, Milosevic JD, Casetti I, Dambruoso I, Pietra D, Boveri E, et al. Efficacy of Ruxolitinib in Chronic Eosinophilic Leukemia Associated With a PCM1-JAK2 Fusion Gene. J Clin Oncol (2013) 31:e269-71. doi: 10.1200/JCO.2012.46.4370

22. Saba N, Safah H. A Myeloproliferative Neoplasm With Translocation $\mathrm{T}(8 ; 9)$ (P22;P24) Involving JAK2 Gene. Blood (2013) 122:861. doi: 10.1182/blood2013-03-487348

23. Schwaab J, Knut M, Haferlach C, Metzgeroth G, Horny H-P, Chase A, et al. Limited Duration of Complete Remission on Ruxolitinib in Myeloid Neoplasms With PCM1-JAK2 and BCR-JAK2 Fusion Genes. Ann Hematol (2015) 94:233-8. doi: 10.1007/s00277-014-2221-y

24. Song I, Lee D, Lee J-H, Jang S, Huh J-R, Seo E-J. A T(8;9)(P22;P24)/PCM1JAK2 Translocation in a Patient With Myeloproliferative Neoplasm and
Myeloid Sarcoma: First Report in Korea. Ann Lab Med (2016) 36:79-81. doi: 10.3343/alm.2016.36.1.79

25. Baer C, Muehlbacher V, Kern W, Haferlach C, Haferlach T. Molecular Genetic Characterization of Myeloid/Lymphoid Neoplasms Associated With Eosinophilia and Rearrangement of PDGFRA, PDGFRB, FGFR1 or PCM1-JAK2. Haematologica (2018) 103:e348-50. doi: 10.3324/haematol. 2017.187302

26. Lee J-M, Lee J, Han E, Kim M, Kim Y, Han K, et al. PCM1 - JAK2 Fusion in a Patient With Acute Myeloid Leukemia. Ann Lab Med (2018) 38:492-4. doi: 10.3343/alm.2018.38.5.492

27. Salehi S, Astle JM, Sadigh S, Lake J, Aikawa V, Tang G, et al. Myeloid Neoplasm With Eosinophilia and PCM1-JAK2 Associated With Acute Promyelocytic Leukemia With PML-RARA. Leukemia Lymphoma (2019) 60:2299-303. doi: 10.1080/10428194.2019.1581927

28. Schwaab J, Naumann N, Luebke J, Jawhar M, Somervaille TCP, Williams MS, et al. Response to Tyrosine Kinase Inhibitors in Myeloid Neoplasms Associated With PCM1 - JAK2, Bcr-Jak2 And ETV6-ABL1 Fusion Genes. Am J Hematol (2020) 95:824-33. doi: 10.1002/ajh.25825

29. Wouters Y, Nevejan L, Louwagie A, Devos H, Dewaele B, Selleslag D, et al. Efficacy of Ruxolitinib in B-Lymphoblastic Leukaemia With the PCM1 JAK2 Fusion Gene. Br J Haematol (2021) 192:1-4. doi: 10.1111/bjh.17340

30. Pozdnyakova O, Orazi A, Kelemen K, King R, Reichard KK, Craig FE, et al. Myeloid/Lymphoid Neoplasms Associated With Eosinophilia and Rearrangements of PDGFRA, PDGFRB, or FGFR1 or With PCM1-JAK2. Am J Clin Pathol (2021) 155:160-78. doi: 10.1093/ajcp/aqaa208

31. Rumi E, Milosevic JD, Selleslag D, Casetti I, Lierman E, Pietra D, et al. Efficacy of Ruxolitinib in Myeloid Neoplasms With PCM1-JAK2 Fusion Gene. Ann Hematol (2015) 94:1927-8. doi: 10.1007/s00277-015-2451-7

32. Chen X, Wang F, Zhang Y, Ma X, Liu M, Cao P, et al. Identification of RNPC3 as a Novel JAK2 Fusion Partner Gene in B-Acute Lymphoblastic Leukemia Refractory to Combination Therapy Including Ruxolitinib. Mol Genet Genomic Med (2020) 8:1-8. doi: 10.1002/mgg3.1110

33. Mayfield JR, Czuchlewski DR, Gale JM, Matlawska-Wasowska K, Vasef MA, Nickl C, et al. Integration of Ruxolitinib Into Dose-Intensified Therapy Targeted Against a Novel JAK2 F694L Mutation in B-Precursor Acute Lymphoblastic Leukemia. Pediatr Blood Cancer (2017) 64:e26328. doi: $10.1002 / \mathrm{pbc} .26328$

34. Ding YY, Stern JW, Jubelirer TF, Wertheim GB, Lin F, Chang F, et al. Clinical Efficacy of Ruxolitinib and Chemotherapy in a Child With Philadelphia Chromosome-Like Acute Lymphoblastic Leukemia With GOLGA5-JAK2 Fusion and Induction Failure. Haematologica (2018) 103:e427-31. doi: 10.3324/haematol.2018.192088

Conflict of Interest: The authors declare that the research was conducted in the absence of any commercial or financial relationships that could be construed as a potential conflict of interest.

Publisher's Note: All claims expressed in this article are solely those of the authors and do not necessarily represent those of their affiliated organizations, or those of the publisher, the editors and the reviewers. Any product that may be evaluated in this article, or claim that may be made by its manufacturer, is not guaranteed or endorsed by the publisher.

Copyright () 2021 Sun, Cai, Chen, Cen, Zhu, Pan, Wu, Sun and Chen. This is an open-access article distributed under the terms of the Creative Commons Attribution License (CC BY). The use, distribution or reproduction in other forums is permitted, provided the original author(s) and the copyright owner(s) are credited and that the original publication in this journal is cited, in accordance with accepted academic practice. No use, distribution or reproduction is permitted which does not comply with these terms. 